\title{
Prepoznatljiva koncilska novost
}

\author{
Programatski ciljevi i širi intelektualni kontekst časopisa \\ Obnovljeni Život
}

Tadija Milikić*

\begin{abstract}
Sažetak
Časopis Obnovljeni Život počeo je izlaziti 1971. godine kao nastavak zabranjenoga časopisa Život (1919.-1944.), koji je ugrađen u novi izdavački koncept kao vlastita tradicija. U radu se najprije sažeto predstavljaju utemeljujući i dugoročni ciljevi ponovno pokrenutoga časopisa na temelju njegova programatskoga teksta. Zatim se daje kratki uvid u ostvarivanje programatskih ciljeva s uporištem na izabrane radove iz dvadeset šestoga godišta, koje je zapravo prvo godište, $u$ kojem se časopis pojavljuje pod novim imenom Obnovljeni Život. U središnjim i najvažnijim dijelovima rada daje se uvid u širi intelektualni kontekst koji je pod snažnim utjecajem Drugoga vatikanskoga sabora i njegova središnjega antropološkoga zaokreta. Svojim naukom i svojim smjernicama taj sabor nadahnjuje ne samo spontanu pojavu časopisa Obnovljeni Život, nego također njegovu kreativnost u stilu i izrazu, kao i u oblikovanju vlastitoga povijesnoga trenutka.
\end{abstract}

Ključne riječi: Obnovljeni Život; znanstveni časopis; Drugi vatikanski koncil; Gaudium et spes; teološka antropologija

\section{Uvod}

Prvi broj časopisa Obnovljeni Život pojavio se je prije stotinu godina početkom nove školske godine 1919./1920. pod imenom Život. Izlazio je redovito kroz četvrt stoljeća sve do 1944. godine. Tada je naglo prestao izlaziti zbog represivnih mjera totalitarnoga komunističkoga režima. Nakon više od četvrt stoljeća (1944.-1971.), kada su nastupili povoljniji uvjeti, ponovno je pokrenut, ali ne pod svojim izvornim imenom Život, nego s novim imenom Obnovljeni Život. Naime, u to je vrijeme već postojao jedan drugi časopis Život. Premda je časopis dobio novo ime, on je na veoma kreativan način ostao vjeran nadahnuću, ciljevima i znanstvenomu profilu časopisa Život, u čiju se je tradiciju ugradio na sasvim

* Dr. sc. Tadija Milikić, Fakultet filozofije i religijskih znanosti Sveučilišta u Zagrebu. Adresa: Jordanovac 110, 10000 Zagreb. E-adresa: tmilikic@ffrz.hr. 
spontan način. U prvom obraćanju svojim čitateljima pod naslovom Riječ Uredništva, u kojem se nalazi i programatski tekst časopisa, uredništvo je istaknulo da uzima za svoj uzor časopis Život, te na način kreativne vjernosti definira vlastite programatske ciljeve (Uredništvo, 1971).

Godine 1919. u drugom broju uredništvo časopisa Život također je objavilo svoj programatski tekst Šta hoćemo (Uredništvo, 1919). Sasvim je razumljivo da postoji snažna paralela između programatskih tekstova i jednoga i drugoga uredništva. Premda su se pojavili u dva povijesna trenutka koji su vremenski udaljeni više od pola stoljeća (1919.-1971.), i premda ih određuju drugačije povijesne, kulturne i intelektualne prilike, u njima se ipak prepoznaje slično nadahnuće, slična motiviranost, slična svrha i slični programatski ciljevi. U skladu sa svojom kršćanskom sviješću, oba su uredništva krenula od analize aktualne religiozne i moralne situacije. U njoj su prepoznala svoj konkretni izazov te definirala svoju svrhu i vlastite programatske ciljeve. I kod jednoga i kod drugoga uredništva može se zamijetiti da svoj središnji izazov raspoznaju u onoj pomoći koju trebaju dati svojim čitateljima u pitanjima vjere i morala, bilo izravno kroz izlaganje središnjih teoloških disciplina, bilo neizravno kroz izlaganje ostalih znanstvenih i srodnih disciplina koje bilo na koji način mogu biti od koristi u ostvarivanju i izgradnji osobnoga ljudskoga, odnosno kršćanskoga života.

Međutim, dobro je ukazati i na neke razlike koje očituju promjenu perspektive, koja je nastupila osobito s promjenom povijesnih prilika i intelektualnoga filozofsko-teološkoga konteksta u razdoblju između prvih desetljeća 20. stoljeća i sredine druge polovice istoga stoljeća. Primjerice, uredništvo časopisa Život polazi od analize aktualne religiozne i moralne situacije, u kojoj se prije svega zamjećuju negativni procesi dekristijanizacije i stvaranja nekršćanskoga mentaliteta, a uredništvo časopisa Obnovljeni Život u svojoj analizi aktualne religiozne i moralne situacije polazi od uočavanja pozitivnih procesa kod ljudi svojega vremena, kao što su usmjerenost i motiviranost na »dublji i temeljitiji duhovni život « (Uredništvo, 1971). Uz zaokret od negativne prema pozitivnoj perspektivi, postoji također zaokret od juridičkih prema personalističkim kategorijama. Primjerice, uredništvo časopisa Život obvezalo se je da će svojim čitateljima pomoći u pitanjima vjere i morala, a uredništvo časopisa Obnovljeni Život obećalo je to isto. Razlika između izraza obvezati se i obećati znakovita je s obzirom na napuštanje normativnih i imperativnih kategorija te preuzimanje onih moralnih i poticajnih koje su primjerenije obnovljenoj svijesti o dostojanstvu ljudske osobe. Uz naglašeni afirmativni i osobni pristup izazovima svojega vremena, uredništvo časopisa Obnovljeni Život očituje također izrazito dijaloški karakter. To čini ne samo kada naglašava da će pomoć koju obećava svojim čitateljima ostvarivati uz suradnju istih čitatelja, nego isto tako kada u njima prepoznaje svoje sugovornike u njihovu punom ljudskom dostojanstvu i, u tom smislu, od njih očekuje njihov kritički sud. Time im zapravo priznaje ne samo njihova neotuđiva prava, nego i njihove neodrecive odgovornosti, kako na razini obnovljene eklezijalne svijesti, tako i na razini sve snažnije društvene svijesti o izgradnji društva, u čijem se središtu nalazi dostojanstvo ljudske osobe (Uredništvo, 1971). 
Ta neupitna promjena perspektive na razini časopisa, koja se može povezati i s promjenom izvornoga imena časopisa u sadašnje ime časopisa, očituje sasvim spontano prihvaćanje novonastale promjene, koja se dogodila s Drugim vatikanskim saborom na razini univerzalne Crkve i dosljedno na razini širega intelektualnoga filozofsko-teološkoga konteksta. Budući da je ta promjena vidljiva i na razini programatskoga teksta časopisa Obnovljeni Život, u kojem se izričito govori o »duhu Koncila« i o »duhu kršćanskog morala koji izvire iz kršćanskog bića « (Uredništvo, 1971), sasvim je opravdano očekivati da se u najvećem broju objavljenih izvornih radova autori često pozivaju na dokumente Drugoga vatikanskoga sabora. Međutim, zanimljivo je istaknuti da se od svih koncilskih dokumenata u svojim radovima autori najviše izravno ili neizravno oslanjaju na pastoralnu konstituciju Gaudium et spes o Crkvi u suvremenom svijetu i deklaraciju Dignitatis humanae o vjerskoj slobodi.

Navedena dva koncilska dokumenta bez sumnje spadaju u one dokumente koji su najviše citirani, izloženi, analizirani, tumačeni ili pak korišteni kao svojevrsni uzor za izgradnju osobnoga stava, izradu vlastitoga stila ili kao podloga za svoju personaliziranu filozofsko-teološku argumentaciju unutar časopisa Obnovljeni Život (Arrupe, 1971, 2-3; Brajičić, 1971a, 38-39; Brajičić, 1971b, 214-218 i 224; Fuček, 1971a, 45-46; Fuček, 1971b, 243-244, 249; Fuček, 1971c; Fuček, 1971d, 529-530; Weissgerber, 1971a, 48; Ivaničin, 1971, 141; Alfaro, 1971; Plačko, 1971; Ćurić, 1971; Mondin, 1971; Čvrljak, 1971). Usklađenost s koncilskim duhom očituje se osobito na razini »razgrađenijih članaka«, kako ih naziva tadašnje uredništvo časopisa Obnovljeni Život (Uredništvo, 1971). Međutim, isti se članci sasvim opravdano, u skladu s današnjim načelima kategorizacije radova unutar akademske zajednice i njezine znanstvene komunikacije, mogu svrstati ne samo u stručne i pregledne, nego i izvorne znanstvene radove koji svojim istraživanjem doprinose razvoju znanstvene spoznaje.

Neki od naslova tih "razgrađenijih", odnosno stručnih i znanstvenih radova su: Situacija Crkve u današnjem svijetu (Arrupe, 1971), U dijalogu s marksistima (Brajičić, 1971a), Problem beskonačnosti materije u sovjetskoj filozofiji (Strilić, 1971), Dokle smo stigli u ekumenizmu? (Schmidt, 1971), Kršćani u današnjem svijetu (Brajičić, 1971b), Kamo ide moderna psihoterapija? (Weissgerber, 1971b), U situaciji modernog razvoja (Fuček, 1971b), Odsutna dimenzija koncilske obnove (Fuček, 1971c), Odakle vjera u evoluciju (Weissgerber, 1971c), Kršćanska vizija ljudskog napretka (Alfaro, 1971), Društveni problemi današnjice (Plačko, 1971) i Sekularizacija kristologije (Mondin, 1971). Uz te izvorne znanstvene radove postoje i druge vrste radova, kao što su prigodni i manji prilozi u kojima se na sličan način ostvaruju programatski ciljevi časopisa Obnovljeni Život. Primjerice, u radu pod naslovom Pluralizam prof. Dragutina Jurića autor poziva na snošljivost u pitanjima vjere i savjesti, upozorava na zajedničku odgovornost u izgradnji vlastite društvene zajednice te podsjeća na općeljudske vrijednosti i dostojanstvo ljudske osobe, koja ima neotuđivo i neodrecivo pravo da »sama sobom upravlja na temelju svoje naravi, koja je slobodna i samoodgovorna «(Ivaničin, 1971, 141). 
Ciljevi koji su istaknuti u programatskom tekstu časopisa Obnovljeni Život, i koji u tom smislu pozadinski upravljaju istraživanjem i izradom kako znanstvenih i stručnih, tako i ostalih radova unutar istoga časopisa, nisu razumljivi u svoj svojoj punini bez onih polaznih ideja, temeljnih smjernica i središnjih ciljeva Drugoga vatikanskoga sabora, koji je svojom pojavom, svojim zaokretom i svojom novom perspektivom bitno odredio širi filozofsko-teološki kontekst, unutar kojega se pojavio časopis Obnovljeni Život. Taj širi kontekst i međunarodni karakter časopisa može se prepoznati također po njegovim autorima koji imaju svoju boravišnu adresu izvan Hrvatske i izvan hrvatskoga, odnosno slavenskoga govornoga područja. Od autora spomenutih u ovom radu to su svakako Juan Alfaro, Pedro Arrupe, Giovanni Battista Mondin i Stjepan Schmidt.

\section{1. “Tako star i tako nov" nauk Drugoga vatikanskoga sabora}

Kao ni bilo koji drugi tako ni taj crkveni sabor nije se pojavio bez svoje duge, zamršene, burne i veoma bogate povijesti i pretpovijesti. S obzirom na razvojni tijek povijesnoga kretanja ljudskoga duha, osobito na području filozofije i teologije, koncil se je oslanjao prije svega na svoj neposredni filozofsko-teološki povijesni kontekst, ali ga je svojom snagom, dubinom i širinom do te mjere nadišao da predstavlja ne samo kraj jednoga, nego i početak novoga razdoblja filozofsko-teološke misli unutar crkvene povijesti. Autoritetom ekumenskoga sabora koncilski otci oslanjaju se također na onu daleku i snažnu teološku povijest koja je prepoznatljiva u svojim velikim povijesnim razdobljima kao što su apostolsko razdoblje, patristika i skolastika. Međutim, uz taj oslonac, kao i svoju vjernost prema evanđelju, koncilski otci isto tako vode računa o novovjekovnim i suvremenim misaonim strujanjima te dosljedno i na veoma zauzet način trude se oko konstruktivnoga i plodnoga dijaloga s neposrednim predkoncilskim povijesnim kretanjima, koja su nastojali na primjeren način ugraditi u svoju bogatu i plodnu koncilsku misao. O novovjekovnim i predkoncilskim misaonim kretanjima govorio sam nešto više u svojem radu, koji se bavi uvidom u nominalizam, empirijske znanosti, neoskolastiku, neotomizam i modernizam, kao širim intelektualnim kontekstom pojave časopisa Život početkom 20. stoljeća (Milikić, 2019, 647-658). Dobro je istaknuti da predkoncilsko razdoblje nije odredilo Drugi vatikanski sabor toliko u smislu njegova kritičkoga odmaka od onoga što nije autentični izraz kršćanske vjere koliko u smislu njegova preuzimanja svega onoga u čemu se prepoznaje autentični racionalni izraz kršćanske vjere i što zahtijeva svoj daljnji razvoj u skladu s novim povijesnim i epistemološkim trenutkom.

Autoritet, snaga, dubina, širina, oštrina i bogatstvo koncilske misli može se prepoznati i po tome što upravo po njoj dobivaju svoje ime i predkoncilska i postkoncilska misaona kretanja unutar crkvene povijesti, osobito one povijesti na području katoličke filozofije i teologije, unutar kojih se i mi danas nalazimo. Koncilska, odnosno postkoncilska misaona kretanja ona su kretanja koja neposredno obilježavaju pojavu i djelovanje časopisa Obnovljeni Život. Budući da je za potrebe ovoga rada potrebno dati sažet i koliko je moguće vjeran uvid u njih, od- 
lučio sam se to učiniti kroz kratki prikaz nastanka i izrade pastoralne konstitucije Gaudium et spes o Crkvi u suvremenom svijetu, s naglaskom na njezinu sadržajnu i argumentacijsku novost. Naime, taj koncilski dokument na najbolji mogući način izlaže upravo najvažnije dimenzije koncilske teološke svježine i njezine neupitne novine, koja se oslanja na svoju starinu. Dobro je naglasiti da je riječ o jednom od najistaknutijih i najprepoznatljivijih dokumenata Drugoga vatikanskoga sabora, koji po svojem imenu, sadržaju, argumentaciji te stilu i načinu na koji se obraća svojim čitateljima predstavlja apsolutnu novost u dvotisućljetnoj povijesti crkvenih sabora. Kao takav taj koncilski dokument predstavlja važan smjerokaz za katoličku filozofiju i teologiju 21. stoljeća i trećega tisućljeća. Dapače, uvidom u opis i povijest njegova nastanka stječe se ne samo bolje razumijevanje koncilske i predkoncilske misli, nego isto tako dobiva primjerenije shvaćanje koncilskih smjernica koje nadahnjuju postkoncilska misaona kretanja, uključujući i ona u kojima se je pojavio i razvio časopis Obnovljeni Život.

\section{Polazne ideje najprepoznatljivijega dokumenta Drugoga vatikanskoga koncila}

Jedno od temeljnih uvjerenja koncilskih otaca, koje se nalazi i u podlozi pastoralne konstitucije Gaudium et spes o Crkvi u suvremenom svijetu uvjerenje je da postoji jedno jedino središte svega stvorenoga, cijeloga svemira i sveukupne ljudske povijesti. To duboko uvjerenje saborskih otaca moglo bi se naći također u korijenu današnje veoma raširene epistemološke svijesti da postoji samo jedna jedina istina, ona puna istina, i da svaka druga istina koja nije identična s njom mora proizlaziti iz nje i $\mathrm{k}$ njoj voditi sa svim onim što u sebi ima od istine, ako se želi barem u tom ograničenom smislu nazvati istinom i barem privremeno biti ono za čim čezne bilo koji ljudski um u svojoj potrazi za punom istinom, bez obzira bio on vjernički ili nevjernički. Imajući na umu tu duboku povezanost istine "ma gdje ona bila", koncilski su se otci dali ne samo na iščitavanje "znakova vremena" u svjetlu evanđelja, nego su se isto tako trudili oko primjerenijega iščitavanja istine evanđelja i njegove Radosne vijesti, i to kroz otvoreno i zauzeto upoznavanje znakova vremena i svijeta u kojem su živjeli. Na taj način koncilski otci, zapravo oslanjajući se na istinu koju traže, nastojali su uspostaviti dijalog između evanđelja i znanosti, Crkve i svijeta, vjere i razuma. Dakako, riječ je o svojevrsnom dijaloškom, pa čak u nekom smislu i proročkom tumačenju ne samo svijeta i čovjeka, nego i samoga evanđelja.

Ta dijaloška krepost proizlazi iz duboke svijesti da je Crkva sastavni i solidarni dio s cijelom ljudskom obitelji i njezinom zajedničkom poviješću (Demmer, 2000, 1-3). Ona najdublja ljudska iskustva kao što su »radost i nada, žalost i tjeskoba [...] osobito siromašnih i svih koji trpe « vjernici bez iznimke dijele zajedno sa svim ostalim ljudima (GS 1). Imajući na umu tu svijest o dubokom jedinstvu cijele ljudske zajednice, Koncil se u toj konstituciji ne obraća samo katolicima, nego i cijelomu ljudskomu rodu. U njoj se on ne bavi samo unutarnjim pitanjima 
vjere kao što su vjerske istine i crkvena disciplina, nego također konkretnim i praktičnim pitanjima čovjeka svojega vremena kao što su znanost, kultura, obitelj, brak i gospodarstvo. Duh dijaloga i solidarnosti koji nadahnjuje cijelu konstituciju izražava se između ostaloga kroz sposobnost autora toga koncilskoga dokumenta da zamijete uz ono negativno također ono pozitivno u svijetu i čovjeku svojega vremena, a zatim i u sposobnosti istih autora da kao kršćani i katolici preuzmu vlastiti dio suodgovornosti za ono što je bilo negativno u tadašnjem svijetu i čovjeku.

Uz duh solidarnosti, dijaloga i neupitnoga jedinstva cijeloga ljudskoga roda, Koncil se također poziva na neodvojivost one unutarnje od izvanjske dimenzije ljudskoga osobnoga života. Zastupajući stav da je ljudski individualni i društveni život jedan jedini, jedinstveni i cjeloviti ljudski život, Koncil s jedne strane prokazuje neprirodnost rascjepa između kršćanske vjere i kršćanskoga života, evanđelja i kulture, Crkve i svijeta, a s druge strane zauzimanjem toga istoga stava Koncil ostvaruje neodrecivu obvezu i neotuđivo pravo Crkve na svoj glas u javnom životu (GS 10). Dapače, svoj zahtjev za prisutnošću unutar javne dimenzije ljudskoga života Koncil opravdava ne toliko nekim partikularnim crkvenim interesom, koliko interesom cijele ljudske zajednice, te svakoga pojedinoga i cijeloga čovjeka. U tom interesu može se prepoznati najkraći opis općega dobra koje je u središtu novovjekovne javne pozornosti, a koje ostaje nerazumljivo i neshvatljivo bez odgovora na temeljno antropološko pitanje o jedinstvenosti, cjelovitosti i nezamjenljivosti bilo kojega ljudskoga bića (GS 3).

$\mathrm{Na}$ tragu upravo istaknute obveze i prava Crkve na njezinu prisutnost $\mathrm{u}$ javnom društvenom prostoru Koncil donosi neka pojašnjenja s obzirom na primjeren odnos između vjere i razuma u izvanjskoj, društvenoj i javnoj dimenziji ljudskoga postojanja (Lorenzetti, 2010, 426; Coccolini, 2010, 399-400). Naime, ako ne postoji deduktivni automatizam, po kojem bi se na temelju univerzalnih vjerskih istina uz pomoć krute racionalne logike došlo do jednoznačnih rješenja konkretnih ovozemnih pitanja, i ako je istina da je crkveni nauk neupitan s obzirom na jedinstvenost svake ljudske osobe uključujući njezinu svijest i savjest, onda je sasvim logično zaključiti da i sami katolici mogu doći da različitih odgovora u rješavanju konkretnih i praktičnih ovozemnih pitanja, odgovora koji međutim moraju ostati unutar okvira temeljnoga kršćanskoga zakona (GS 42; Chiavacci, 2007, 101-105). Taj zakon, koji je i temeljni zakon jedinstva, prema koncilskim otcima nije samo naravnoga, nego i nadnaravnoga tipa. Taj temeljni kršćanski zakon koncilski otci prepoznaju u Kristu koji čovjeku pruža svjetlo i snagu za ostvarivanje svojega najvišega poziva. Prema koncilskim otcima tek u Kristu čovjek pronalazi »ključ, središte i cilj sve ljudske povijesti«, ono što je nepromjenljivo i što se nalazi na dnu svih mijena i promjena (GS 10; Häring, 1973, 11). Tu svoju teološku argumentaciju koncilski otci oslanjaju na kristologiju, koja ima svoj temelj u poslanici Kološanima, u kojoj se sasvim jasno tvrdi da je sve stvoreno po Kristu i za Krista (Kol 1,15-20), odnosno u poslanici Efežanima i Otkrivenju, u kojima se tvrdi da tek u Kristovu Duhu čovjek putuje prema konačnomu dovršenju ljudske povijesti, tj. prema Kristu koji obuhvaća sve stvoreno 
(Ef 1,10) i koji je »Prvi i Posljednji. Početak i Svršetak « (Otk 22, 12-13; GS 45; Chiavacci, 2007, 284-286).

\section{Oblici kritičke asimilacije}

\subsection{Autonomija, sloboda i ljudsko dostojanstvo}

U skladu sa svojim promatranjem znakova vremena, Koncil s pravom zapaža da ljudsko društvo polako napušta srednjovjekovnu statičnu i preuzima dinamičnu sliku svijeta, te da se uz pozitivne susreće i s negativnim vidovima novovjekovnoga napretka. Bez obzira što odbacuje pretjerani prosvjetiteljski optimizam, Koncil prihvaća opravdani zahtjev prosvjetiteljske misli kad je u pitanju njezin središnji problem, koji predstavlja jednu od najistaknutijih značajki duha našega vremena (Demmer, 2000, 22-23). Opravdani zahtjev prosvjetiteljstva Koncil preuzima i oslanja na svoju teologiju stvaranja. To on čini kroz svoj nauk o zakonitoj autonomiji stvorene stvarnosti, iz koje također proizlazi zakonita autonomija znanosti, kulture i politike (GS 36). Kroz taj nauk koncilski otci odvažno i snažno odbacuju ne samo religiozni integralizam, nego isto tako odbacuju neprihvatljivi autonomizam i materijalistički humanizam. Na taj način oni daju snažnu potporu za primjerenije razumijevanje uloge laika te važnosti njihove stručnosti unutar Crkve i svijeta (GS 36; LG 37; Kasper, 2005).

Uz taj nauk o ispravno shvaćenoj autonomiji ovozemnih stvarnosti konstitucija donosi još jedan nauk koji se pojavljuje na tragu novovjekovne misli o ljudskim pravima. Koncil je preuzeo taj nauk, ali mu je dao svoje vlastito teološko utemeljenje. Prije svega on se oslanja na teologiju stvaranja, po kojoj je svaki čovjek stvoren na Božju sliku i priliku (Post 1,27), a zatim i na kristološku teologiju, po kojoj »misterij čovjeka postaje doista jasan jedino u misteriju utjelovljene Riječi« (GS 22). Taj teološki oslonac omogućio je Koncilu da u svojoj deklaraciji o vjerskoj slobodi, na načelima vlastite teološke epistemologije, sasvim jasno istakne važnost i nezamjenjivu ulogu ljudske slobode, na temelju koje ljudska osoba ima ne samo neotuđivo, nego i neodrecivo pravo tražiti istinu i prosuđivati ju u skladu s vlastitom sviješću i savješću oslanjajući se na svoje vlastito ljudsko dostojanstvo, osobito u vjerskoj stvari. »A naredbe božanskog zakona čovjek prima i prihvaća posredstvom svoje savjesti; nju mora vjerno slijediti u svemu svome djelovanju, da dođe do Boga, svoga cilja« (DH 3).

Koncil ne gleda toliko na apstraktno pravo koje pripada istini koliko na konkretno pravo koje pripada osobi. S tim koncilskim dokumentom o vjerskoj slobodi polako su napuštene juridičke kategorije koje su opterećene subjektivizmom, liberalizmom i individualizmom, i sve više unutar dokumenata crkvenoga učiteljstva pojavljivale su se personalističke kategorije koje promiču čovjeka i dostojanstvo njegove osobe. Novi personalistički oblik mišljenja osobito dolazi do izražaja kada Koncil govori o kršćanskom pozivu na spasenje i o Božjem izvornom planu za čovjeka. Primjerice kada govori o »uzvišenom pozivu vjernika u Kristu« (OT 16; Häring, 1973, 81-319). Te nove personalističke kategorije također dolaze do 
izražaja kada Koncil naglašava dijalošku strukturu kršćanskoga poziva te važnost i nužnost osobne zauzetosti u tom dijalogu. Na taj način Koncil želi između ostaloga istaknuti da se kršćanski život ne iscrpljuje u izvanjskom provođenju neosobnoga zakona, nego u osobnom i zauzetom odgovoru na isto tako osoban i zauzet poziv kojim se Bog obraća ne samo svakomu kršćaninu u Isusu Kristu, nego i svakomu čovjeku u njegovoj svijesti i savjesti (OT 16; GS 16; Demmer, 2000, 4-7; Häring, 1973, 11-15).

Dosadašnji govor o autonomiji, slobodi i ljudskom dostojanstvu daje naslutiti da je središnji objekt koncilske konstitucije zapravo čovjek, što ona i potvrđuje u svojem dvanaestom broju kada čovjeka naziva središtem i vrhuncem svega stvorenoga (GS 12). Premda je to središnja novovjekovna tvrdnja, koncilski ju otci nisu preuzeli kao takvu, nego su ju filtrirali kroz svoj vlastiti teološki sustav te su joj dali svoje vlastito teološko utemeljenje, uvijek ostavši vjerni primatu, koji u njihovoj teološkoj refleksiji ima Božja Riječ. Na taj način oni su pokazali ne samo duboku svijest o vlastitom vjerničkom identitetu, nego isto tako sposobnost vlastitoga teološkoga, odnosno intelektualnoga organizma da asimilira sve ono što je dobro i istinito u ljudskoj riječi, zbog čega se kršćanska mudrost može s pravom nazvati i specifično kršćanskom i duboko ljudskom. U tom smislu, kao što se autonomija i sloboda shvaćaju unutar teološkoga okvira, unutar istoga okvira razumijeva se također ljudsko dostojanstvo, odnosno čovjek kao središte i vrhunac svega stvorenoga. Svojim antropološkim naukom Koncil nije otvorio put nikakvomu antropocentrizmu ili naturalizmu u novom ruhu (Sale, 2007), nego je donio svoj vlastiti teološki, evanđeoski, kristološki i antropološki nauk. To on čini u skladu sa zahtjevima punine objavljenoga nauka, kao i sa zahtjevima suvremene epistemološke misli. A to je zapravo najvažniji doprinos toga koncilskoga dokumenta, koji je svojom teološkom antropologijom na početku druge polovice 20. stoljeća ušao među začetnike te znanstvene discipline i ponudio vlastiti odgovor na središnje novovjekovno pitanje o čovjeku, njegovoj naravi i smislu njegova postojanja (Kasper, 2005; Ladaria, 1997, 26).

Svojim realističnim i dramatičnim pogledom na čovjeka Koncil se je udaljio od onoga pretjeranoga prosvjetiteljskoga optimizma. On je prepoznao i veličinu i bijedu ljudskoga bića: njegovo uzvišeno dostojanstvo i »izvornu (naravnu) dobrotu « (Rousseau, 1781), ali isto tako njegovu grješnost (GS 13) i smrtnost (GS 18). Koncil je izbjegavao svaki dualizam koji bi ga odveo bilo u personalizam koji vodi u zaborav naravi, bilo u naturalizam koji ne vodi računa o osobi. I jedna i druga krajnost ne daju dužnu pozornost cjelovitoj i jedinstvenoj strukturi ljudske osobe. Stoga, Koncil nije doveo u pitanje važnost i ulogu ni materijalne ni duhovne dimenzije ljudske naravi, ali ipak sasvim je jasno istaknuo da je ljudski razum ono po čemu čovjek nadilazi sav materijalni svijet i da zato upravo čovjek ima posebno mjesto i posebnu ulogu u istom svijetu (GS 14-15).

U kontekstu ljudske razumne i duhovne naravi, Koncil nije mogao izbjeći govor i o ljudskoj slobodi. U njoj je on prepoznao »izuzetan znak Božje slike u čovjeku«. Djelovati u skladu sa svojim svjesnim i slobodnim izborom, a ne pod unutarnjim ili izvanjskim pritiskom, zahtjev je koji proizlazi iz samoga ljudskoga 
dostojanstva, smatra Koncil (GS 17; STh I-II, Prooemium). Međutim, isti Koncil nije shvaćao čovjeka kao monadu, kao ontološku jedinicu koja bi bila zatvorena u samu sebe i izolirana od svega ostaloga. Naprotiv, upravo u ljudskoj slobodi, te racionalnoj, odnosno duhovnoj ljudskoj naravi, Koncil je identificirao one dublje razloge zbog kojih čovjek ulazi u veoma složene odnose uzajamne uzročnosti, koji se ne mogu svesti tek na onu izvanjsku razinu, primjerice animalnu, vegetativnu, fizičku, biološku i kemijsku. I konačno, Koncil je naglasio da svoju osobnu, individualnu, društvenu, dijalošku i duhovnu narav, koja je veoma složena, ali i jedinstvena, čovjek sasvim spontano otkriva ne samo na naravnoj, nego i na nadnaravnoj, odnosno transcendentnoj razini svojega postojanja (GS 12; International Theological Commision, 2009, 51-63).

\subsection{Subjektivnost i objektivnost}

Govor o osobnoj, društvenoj i transcendentnoj razini ljudskoga postojanja Koncil osobito dotiče u svojem nauku o osobnoj savjesti. U njemu, barem u glavnim crtama, uspostavlja odnos i sa središnjim pitanjima novovjekovne misli o ljudskom subjektivizmu i objektivizmu (Demmer, 2000, 4-7). Prema Koncilu, osobna je savjest najskrovitije ljudsko središte u kojem se čovjek susreće sa samim sobom, i u kojem se nalazi sam s Bogom, koji mu progovara u njegovoj osobnoj nutrini (GS 16). U tom susretu sa samim sobom i s Bogom kršćanska teologija prepoznaje ne samo zahtjevnost, nego i uzvišenost ljudskoga života (DH 2-3). Osobna savjest prepoznatljiva je odlika ljudskoga postojanja i najdublji temelj vlastite osobne slobode pred navalom bilo koje izvanjske prosudbe, tiranije ili isključivosti, bez obzira bila ona otvorenoga ili prikrivenoga tipa unutar demokratskoga ili nedemokratskoga društva. Upravo u savjesti čovjek otkriva uzvišenost i zahtjevnost svojega dostojanstva da živi u skladu sa svojom savješću i sa sviješću da ga u tom prosuđuje sam Bog. To poimanje savjesti i ljudskoga dostojanstva nezaobilazan je i nikad dovoljno naglašen smjerokaz u povijesti ljudskoga duha (Demmer, 2004, 244-248).

Koncil naglašava da je pitanje osobne savjesti u najužoj vezi s pitanjem o Bogu. Oslanjajući se također na prijašnju tradiciju, osobito onu patrističku i biblijsku, Koncil s jedne strane ukazuje na savjest kao na hermeneutičku privilegiranu instancu, u kojoj Bog čovjeku otkriva svoj plan s čovjekom, a s druge strane ukazuje na savjest kao na čovjekovo najskrovitije središte iz kojega izviru sve pojedinačne ljudske odluke. Takvo poimanje savjesti prešutno pretpostavlja da u čovjeku postoji neposredna živa svijest o Bogu, koja nadilazi svaku vrstu empirijskoga iskustva (Demmer, 2004, 248-257). U toj i tako shvaćenoj svijesti i savjesti čovjek se susreće s najvišim moralnim načelima ljubavi prema Bogu i bližnjemu. Kad ih dohvaća, prate ga sigurnost i nepogrešivost, ali isto tako i svijest da istim načelima ne može raspolagati te da ih mora prihvatiti kao temeljna načela svojega ljudskoga života (Capone, 1986). To znači da koncilski pojam savjesti ne daje zeleno svjetlo samovolji, nego ističe da je jedino u savjesti i po savjesti moguće na primjeren i čovjeka dostojan način ostvarivati susret između subjektivnosti i objektivnosti, subjektiviteta i objektiviteta, čovjeka i Boga (DH 2-3; GS 13). 
Dapače, upravo u savjesti Koncil prepoznaje temeljni oslonac za susret i dijalog s bližnjima, ne samo s vjernicima: katolicima, kršćanima i nekršćanima, nego i sa svim ostalim ljudima uključujući i ateiste. »Time što su vjerni savjesti, kršćani se povezuju s ostalim ljudima u traženju istine «, tvrdi Koncil (GS, 16). Na taj način saborski otci zapravo stavljaju u prvi plan činjenicu da ono što povezuje kršćane i nekršćane nije toliko istina koja se posjeduje koliko istina koja se traži. Svijest o trajnoj ljudskoj potrazi za punom istinom otvara na sasvim spontan način koncilski nauk o ispravnoj i pogrešivoj savjesti. Ne ulazeći sustavnije u tu problematiku, želio bih tek podsjetiti da se na temelju koncilskoga nauka može reći da savjest nije samo Božja, nego i ljudska riječ, da nije samo nepogrešiva, nego i pogrešiva. Štoviše, uz mogućnost da pogriješi, savjest nažalost ima mogućnost također postati gotovo slijepa s obzirom na objektivne norme moralnosti i dosljedno najviše ljudske vrijednosti, ako »se čovjek malo brine da traži istinu i dobro«. Ta opomena saborskih otaca nalazi se na samom kraju središnjega koncilskoga govora o dostojanstvu moralne savjesti, što ukazuje na središnju važnost njezina značenja u kontekstu koncilske poruke suvremenomu čovjeku (GS 16).

Koncilski nauk o savjesti uvodi nas također u dublje promišljanje odnosa koji postoji između onoga što je nadnaravno i naravno, objektivno i subjektivno, univerzalno i konkretno, apsolutno i relativno na antropološkoj razini. Bolje razumijevanje tih odnosa Koncil daje u kristološkom utemeljenju svoje antropologije. Kao teolozi saborski otci svjesni su da je govor o čovjeku nepotpun i bitno manjkav ako ne uključuje govor o Bogu, koji se čovjeku objavljuje i koji u svojem jedinorođenom Sinu otkriva čovjeku njegovu istinsku ljudsku narav. Tek u Isusu Kristu čovjek može upoznati savršeno i paradigmatsko ostvarenje svoje ljudske naravi: savršenoga Čovjeka koji je u prvom Adamu imao svoju sliku. Tek u Isusu Kristu čovjek može upoznati izvorni Božji plan o sebi samom, svoj uzvišeni poziv, i konačno uzor svoje eshatološke ostvarenosti (GS 22; Ladaria, 1997, 26-38). Na temelju te poveznice između čovjeka i Krista, odnosno antropologije i kristologije, Koncil je mogao doći do boljega razumijevanja novovjekovnoga antropološkoga pitanja. U skladu s tim razumijevanjem Koncil je mogao izraditi teološku antropologiju koja je kristološki utemeljena, koja je u skladu s epistemološkim standardima suvremenoga povijesnoga trenutka i, konačno, koja nudi vlastiti teološki, kršćanski, evanđeoski i kristološki odgovor na temeljno i središnje novovjekovno pitanje o čovjeku, njegovoj naravi, pozivu i smislu postojanja.

\section{Koncilska antropologija}

\subsection{Uvid u širi povijesni kontekst koncilske antropologije}

Da bi se koncilska antropologija mogla koliko je moguće bolje razumjeti, dobro ju je staviti u njezin širi kontekst koji na nju bitno utječe. To je kontekst zapadne kulture. Iako se u njezinu središtu oduvijek nalazi čovjek, ipak tek u novovjekovlju dolazi do razvoja antropologije u smjeru samostalne znanstvene discipline. Taj razvoj dosiže svoj vrhunac u prvoj polovici 20. stoljeća, ali je bitno 
određen tzv. antropološkim zaokretom, koji se je počeo događati odvajanjem antropološke problematike od one metafizičke i teološke, osobito s pojavom nominalističkih ideja koje usmjeruju ljudski duh na stvarnost u njezinoj fizičkoj konkretnosti (Demmer, 2000, 25-29). Uz taj treba spomenuti i snažni Descartesov utjecaj, koji je svojim dualističkim tumačenjem čovjeka bitno odredio daljnji smjer antropologije, koja se u svojem razvoju koristi i empirijskom i humanističkom metodom, ovisno o tom je li riječ o misaonoj ili protežnoj ljudskoj stvarnosti (Kasper, 1996).

Međutim, snažnim razvojem empirijskih znanosti i njezinim preuzimanjem neprimjerene dominacije u području znanosti, filozofska i teološka racionalnost sve se više i više svode na onu prirodoslovnu racionalnost, zbog koje primjerice filozofija povijesti postaje povijest filozofije koja se isključivo koristi empirijskom metodom (Coccolini, 2010, 395-400, osobito 397-398). Takvomu razvoju antropologije, koji sve više i više svodi čovjeka na protežnu stvarnost, treba pridodati također snažni razvoj i prihvaćanje evolucionističke teorije, koja dodatno na sebi vlastit način osnažuje temeljno novovjekovno pitanje: Tko je čovjek i koja je njegova narav? Nastojeći dati odgovor na to pitanje, u prvoj polovici 20. stoljeća javljaju se različite antropologije filozofskoga tipa. One ukazuju na potrebu nadilaženja Descartesova dualizma i dosljedno na potrebu postuliranja jedinstvene ljudske naravi, koja supstancijalno povezuje i ostvaruje čovjekov misaoni subjektivitet i njegov protežni objektivitet (Kasper, 1996).

U tom kontekstu pojavio se je i Drugi vatikanski sabor, koji je kroz pastoralnu konstituciju Gaudium et spes o Crkvi u suvremenom svijetu nastojao ući u dijalog sa suvremenom kulturom i dati svoj doprinos u nadvladavanju najveće krize novovjekovnoga čovjeka, one antropološke. Uvide koje ima na temelju svojega vlastitoga vjerničkog razuma, tj. razuma koji je prosvijetljen vjerom, evanđeljem, i puninom Objave u Isusu Kristu, Koncil je nastojao podijeliti u kontekstu otvorenoga dijaloga koji se svjesno i nesvjesno već odvija na razini cijele ljudske zajednice (Demmer, 2000, 29-33). Svoje uvide oslanja osobito na odnos koji postoji između antropologije i kristologije, a pri tom vodi računa ne samo o temeljnim idejama kojima se nadahnjuje pri izradi antropoloških tvrdnji, nego i o ulozi istih tvrdnji u kontekstu središnje poruke pastoralne konstitucije Gaudium et spes.

\subsection{Temeljne smjernice u izradi koncilske antropologije}

Središnja ideja vodilja u skiciranju i oblikovanju konačnoga teksta konstitucije Gaudium et spes bila je Crkva, i to pod dva vida: svijest koju ima o sebi samoj (Ecclesia ad intra) i svijest koju ima o svojem odnosu sa suvremenim svijetom u njegovim vlastitim prilikama (Ecclesia ad extra). Na pitanje treba li se odnosom između Crkve i svijeta baviti pod teološkim ili kulturnim vidom, Koncil pronalazi odgovor s jedne strane u svojoj obnovljenoj ekleziološkoj svijesti da je Crkva univerzalni sakrament spasenja (LG 9 i 48), a s druge strane u svojoj svijesti koju ima kao Crkva određenoga povijesnoga razdoblja unutar isto tako određene kulture i epistemologije. U tom smislu, Koncil nastoji pronaći zajedničku perspektivu koja bi očitovala unutarnju povezanost teološke i kulturne, odnosno nadnaravne 
i naravne dimenzije jednoga jedinoga, jedinstvenog i cjelovitog kršćanskog, odnosno ljudskog života.

U sastavni dio te problematike ulazi također jasno i precizno određivanje sugovornika i dosljedno oblika argumentacije koja bi trebala biti racionalno shvatljiva i prihvatljiva svima koji su uključeni u spomenuti odnos Crkve s cijelim svijetom. Stoga, u skladu sa svojom sviješću da je »Crkva sakrament ili znak i oruđe najtješnjeg sjedinjenja s Bogom i jedinstva cijeloga ljudskog roda« (LG 1), Koncil se obraća ne samo katolicima, nego i cijelomu svijetu. Ako se ne želi samo govoriti o svijetu, nego sa svijetom, tj. ako sugovornici nisu samo katolici, kršćani i vjernici, nego i svi ostali suvremenici, onda jezik konstitucije treba biti svima primjeren. To bi značilo da argumentacija s jedne strane treba biti u skladu s vjerničkom sviješću koja u njoj želi izraziti svoj katolički identitet, a s druge strane ista argumentacija treba biti u skladu s univerzalnom ljudskom sviješću koja se također izriče u skladu s vlastitim identitetom svojega povijesnoga razdoblja. Upravo stoga, u svijesti žive vjere, koja je u neprestanoj potrazi isto tako za živim razumom i njegovim vlastitim kreativnim radom u skladu s njegovom izvornom i zauzetom otvorenošću prema punoj istini, Crkva napušta obrambeni, a zauzima dijaloški, konstruktivan i proročki stav, uvijek se upravljajući svjetlom evanđelja Isusa Krista i nastojeći doprinijeti novoj inkulturaciji kršćanstva u suvremenom svijetu.

$\mathrm{Na}$ tragu tih pitanja počeo se malo-pomalo pojavljivati odgovor u obliku teološke argumentacije povijesno-spasenjskoga tipa. Ona je u sebi objedinjavala kako brigu oko vlastite kršćanske posebnosti, tako i brigu oko univerzalne relevantnosti uvida koji proizlaze iz iste kršćanske posebnosti. Tom svojom kritičkom i konstruktivnom argumentacijom, Koncil je nastojao s jedne strane obraniti i zaštititi vlastiti vjernički identitet, a s druge strane ukazati na racionalnu shvatljivost i prihvatljivost uvida vjerničke inteligencije u kontekstu suvremenoga povijesnoga trenutka (Kasper, 1996; Demmer, 2000, 22-28). Na pitanje treba li svoju teološku argumentaciju strukturirati unutar ekleziološkoga ili antropološkogaa intelektualnoga horizonta, Koncil se je u konačnici odlučio za drugi izbor, između ostaloga smatrajući da na taj način može bolje istaknuti jedinstvenost naravnoga i nadnaravnoga ljudskoga poziva, te primjerenije odgovoriti na središnje pitanje novovjekovnoga čovjeka, koji je kroz rastuću spoznaju materijalnoga svijeta i njegovih zakona sve više gubio svijest o sebi samom, svojem pozivu i smislu svojega ljudskoga života (Benedikt XVI., 2007).

Izbor teološke argumentacije povijesno-spasenjskoga tipa unutar antropološkoga intelektualnoga horizonta omogućio je Koncilu jedinstvenu platformu za dijalog unutar i izvan Crkve s jedne strane, a s druge strane dao mu je oslonac za početak dijaloga s novovjekovnim čovjekom, oslonac koji je bio prikladan i primjeren epistemološkoj svijesti u tom posebnom povijesnom trenutku i razdoblju ljudskoga duha. Oslanjajući se na antropologiju kao na jedinstvenu dijalošku platformu, Koncil se obraća i onima unutar Crkve i onima izvan Crkve, osobito kada želi istaknuti jedinstvenost naravnoga i nadnaravnoga ljudskog poziva. Stoga, prvima ukazuje na važnost i nužnost njihove osobne zauzetosti u očuvanju, 
izgradnji i preobrazbi naravnoga svijeta (GS 36), a drugima pak ukazuje na njihov nadnaravni poziv koji nadilazi materijalnu stvarnost naravnoga svijeta (OT 16; Kasper, 1996).

I u jednom i u drugom slučaju Koncil se je uz teologiju stvaranja sve više oslanjao na teologiju spasenja. To je posve u skladu s obnovljenom eklezijalnom sviješću, koja je osnažila povijesno-spasenjsku, odnosno kristološku teološku misao. U njoj je Koncil prepoznao ne samo najbolji izraz posebnosti kršćanske poruke, nego i racionalni izraz koji bi bio najprimjereniji standardima epistemološkoga zahtjeva suvremenoga čovjeka za racionalnom shvatljivošću i prihvatljivošću. Budući da Koncil u svojoj kristološkoj misli prepoznaje najbolju poveznicu s novovjekovnim antropološkim pitanjem, on upravo na toj kristološkoj razini nastoji najprije utvrditi poveznicu između Boga i čovjeka, a zatim izbjeći kako kristologiju, koja dovodi u pitanje zajedničku antropološku dijalošku osnovu, tako i antropologiju, koja ograničava, umanjuje ili čak dokida posebnost kršćanske poruke. Upravo u njoj, tj. evanđeoskoj poruci Isusa Krista, vjernička inteligencija pronalazi vlastiti kršćanski odgovor na središnje pitanje svojih suvremenika: tko je čovjek, koji je njegov poziv i smisao njegova postojanja (GS 10 i 22; Ladaria, 2015; OT 16).

\subsection{Kristološka antropologija}

S pitanjem odnosa između antropologije i kristologije Koncil se je suočio s jednim od temeljnih problema suvremene teologije i svojim rješenjima bitno odredio daljnja postkoncilska misaona kretanja na tom području (Ladaria, 1997, 26-38, osobito 28; Ladaria, 2015, 1-3). Prije svega, nameće se pitanje: Pretpostavljaju li kristološke tvrdnje one antropološke ili je obratno? U prvom slučaju s lakoćom se otvara i dodatno pitanje: izvodi li se kristologija iz antropologije i ne gubi li u tom slučaju svoju kršćansku posebnost, a u drugom pak slučaju opravdano je pitati se je li uopće moguća bilo koja teologija bez antropoloških kategorija i oslonca na antropološke tvrdnje. Uz već istaknuti izazov, Koncil se je susreo također s izazovom temeljnih kristoloških pojmova i soterioloških kategorija kao što su osoba, narav, žrtva i zadovoljština, s obzirom na njihovu aktualnu relevantnost i značenje unutar svakidašnjega životnoga iskustva suvremenoga čovjeka i njegovih temeljnih pitanja, koja su bitno obilježena krizom antropološke svijesti.

U svojem nastojanju da što je moguće bolje utvrdi odnos između kristologije i antropologije, Koncil je uočio da antropološki zaokret i s njim povezana pitanja i poteškoće, ne predstavljaju samo dobar oslonac za početak dijaloga sa suvremenom kulturom, nego isto tako jasno ukazuju na kritičnu točku unutar samoga teološkoga promišljanja, koja se i prije pojavljivala primjerice na razini dileme kod utvrđivanja odnosa između »kristologije odozgo« i »kristologije odozdo« (Mondin, 1971). Tu kritičnu točku teološke refleksije Koncil je prepoznao u dilemi između identiteta i relevantnosti kršćanske poruke. Nastojeći voditi računa i o jednom i o drugom, Koncil je u konačnici došao do rješenja koje polazi od svijesti o jedinstvenom povijesno-spasenjskom poretku, tj. poretku koji u sebi objedinjuje i poredak stvaranja i poredak spasenja. To polazište omogućilo je Koncilu prije 
svega da se u svojoj teološkoj refleksiji može s pravom oslanjati kako na antropološke tako i kristološke tvrdnje, a zatim da unutar tih posljednjih može, isto tako s pravom, imati kriterij i trajni intelektualni horizont za ispravno razumijevanje, shvaćanje, elaboriranje i izlaganje antropoloških tvrdnji (Kasper, 1996).

Imajući na umu sve do sada rečeno, Koncil je došao do središnje rečenice svoje antropologije na temelju koje se ona može opravdano nazvati teološkom, kršćanskom i kristološkom antropologijom. Ta rečenica glasi: »Misterij čovjeka postaje doista jasan jedino u misteriju utjelovljene Riječi« (GS 22). Ta koncilska tvrdnja ukazuje na veoma usku poveznicu koja postoji između čovjeka i Krista. Tu tvrdnju Koncil oslanja na svoj nauk o Božjoj slici i to na dvostruk način. Prije svega zato što se Božja slika u čovjeku ostvaruje potpuno tek u njegovu zajedništvu s Bogom, kakvo je već ostvareno na nenadmašiv način u Isusu Kristu, koji je »slika nevidljivog Boga« (Kol 1,15). A zatim i zato što se Božjoj slici u čovjeku, koja je izvornim grijehom izgubila svoju sličnost s Bogom, njezina sličnost s Bogom vraća tek u Isusu Kristu, koji nije samo pravi, nego i savršeni Čovjek (GS 22; Ladaria, 2015). Na tragu dosadašnje refleksije unutar ovoga rada može se zaključiti da Koncil u svojoj teološkoj antropologiji povezuje prije svega objavu Boga s objavom čovjeka, a zatim ukazuje na Isusa Krista kao na vrhunac i puninu objave Boga i čovjeka čovjeku. To on čini kada sasvim jasno i razgovijetno tvrdi da upravo i jedino Isus Krist potpuno »objavljujući misterij Oca i njegove ljubavi [također] potpuno otkriva i čovjeka njemu samomu te mu objavljuje uzvišenost njegova poziva« (GS 22). Tom rečenicom Drugi vatikanski koncil, na najbolji mogući način, daje svoj doprinos u nadvladavanju najveće krize novovjekovnoga čovjeka, koji je sve više gubio svijest o sebi samom, svojem pozivu i smislu svojega ljudskoga života. U toj koncilskoj rečenici na posve sažet način nalazi se sažet teološki, kršćanski, evanđeoski, kristološki i antropološki odgovor vjerničke inteligencije na pitanje o naravi, pozivu i smislu ljudskoga postojanja.

\section{Zaključak}

Jedan od najistaknutijih i najprepoznatljivijih dokumenata Drugoga vatikanskoga sabora svakako je pastoralna konstitucija Gaudium et spes o Crkvi u suvremenom svijetu. Njezine polazne ideje, temeljne smjernice i središnji ciljevi očituju dijaloški stav te visoko zrelu i odgovornu intelektualnu sposobnost koncilskih otaca da uđu u dijalog sa suvremenim svijetom. Osim toga, svjedoče duboku svijest o vlastitom kršćanskom identitetu koncilskih otaca i to kroz njihov poseban doprinos u nadvladavanju najveće krize novovjekovnoga čovjeka, koji je kroz rastuću spoznaju materijalnoga svijeta i njegovih zakona sve više gubio svijest o sebi samom, svojem pozivu i smislu svojeg ljudskoga života. Koncilski dijaloški stav i preuzimanje opravdanih zahtjeva suvremenoga svijeta, osobito na području ljudske autonomije, ljudske slobode i ljudskoga dostojanstva, nisu bili znak slabosti i pukoga prihvaćanja rezultata novonastaloga povijesnoga razvoja, nego izraz intelektualne snage i kritičkoga potencijala koncilskih otaca, koji se 
oslanjaju prije svega na vlastita teološka i evanđeoska načela u izgradnji zajedničke perspektive i jedinstvenoga pogleda na svijet i čovjeka u njemu.

Autori članaka objavljenih u časopisu Obnovljeni Život prepoznali su novost koncilske misli i njezin izazov u svojem vlastitom spisateljskom filozofsko-teološkom radu. S lakoćom su se uskladili sa stavom, stilom i načelima koncilskih otaca. To su činili na hrabar i veoma konstruktivan način. Na tragu koncilske otvorenosti, dijaloškoga stava i svoje usmjerenosti na dobro svakoga i cijeloga čovjeka, očitovali su svoju vjernost evanđeoskoj mudrosti, koja je prepoznatljiva u savjetu sv. Pavla apostola i opomeni sv. Ireneja Lionskoga (130.-202.). Prvi mudro savjetuje: »Sve provjeravajte: dobro zadržite, svake se sjene zla klonite! (1 Sol 5,21), a drugi snažno opominje: »Gloria enim Dei vivens homo (Živi čovjek je slava Božja)«(Irenej, 1857, 1037; Contra Haereses, lib. 4, 7). Poput njih i koncilskih otaca, autori radova u časopisu Obnovljeni Život nastojali su doprinijeti konstruktivnomu i plodnomu dijalogu u izgradnji zajedničke ljudske obitelji i jedinstvene perspektive u razumijevanju čovjeka i shvaćanju svijeta u kojem se nalazi čovjek.

Na temelju programatskih ciljeva uredništva časopisa Obnovljeni Život, kao i na temelju njihova širega intelektualnoga konteksta, koji je bio pod snažnom dominacijom Drugoga vatikanskoga sabora, te njegovih polaznih ideja, temeljnih smjernica i središnjih ciljeva, može se ustvrditi da je časopis Obnovljeni Život u visokom stupnju ispunio svoju zadaću.

\section{Literatura:}

Alfaro, Juan (1971). Kršćanska vizija ljudskog napretka. Obnovljeni Život, 26(5), 407-412. Arrupe, Pedro (1971). Sitacija Crkve u današnjem svijetu. Obnovljeni Život, 26(1), 2-13.

Benedikt XVI. (2007). Address of his Holiness Benedict XVI to the Participants in the International Congress on Natural Moral Law. The Holy See. URL: https:// w2.vatican.va/content/benedict-xvi/en/speeches/2007/february/documents/hf_benxvi_spe_20070212_pul.html (20.10.2019.)

Biblija. Adalbert Rebić, Jerko Fućak i Bonaventura Duda (ur.), Biblija: Stari i Novi zavjet s uvodima i bilješkama iz La Bible de Jérusalem. Zagreb: Kršćanska sadašnjost, 2003.

Brajičić, Rudolf (1971a). U dijalogu s marksistima. Obnovljeni Život, 26(1), 35-39.

Brajičić, Rudolf (1971b). Kršćani u današnjem svijetu. Obnovljeni Život, 26(3), 214-225.

Capone, Domenico (1986). La teologia della coscienza morale nel concilio e dopo il concilio. Studia Moralia, 24(2), 221-249.

Chiavacci, Enrico (2007). Teologia morale fondamentale. Assisi: Cittadella Editrice.

Coccolini, Giacomo (2010). Un'etica comune alle sapienze religiose e filosofiche. Rivista di teologia morale, 42(3), 395-400.

Čvrljak, Krešimir (1971). Uz jednu značajnu 150-obljetnicu: Čovjek na raspelu patnje i podvojenosti. Obnovljeni Život, 26(6), 561-566.

Ćurić, Josip (1971). »Šesti čovjek.« Obnovljeni Život, 26(6), 497-506.

Demmer, Klaus (2000). Shaping the Moral Life: An Approach to Moral Theology. Washington: Georgetown University Press.

Demmer, Klaus (2004). Fondamenti di etica teologica. Assisi: Cittadella Editrice. 
DH. Dignitas humanae. (7. prosinca 1965.) Drugi vatikanski koncil, Deklaracija Dignitas humanae o vjerskoj slobodi. U: Josip Turčinović (ur.), II vatikanski koncil: Dokumenti: Latinski i hrvatski (str. 468-489). Zagreb: Kršćanska sadašnjost, 1970.

Fuček, Ivan (1971a). Vjera u procjepu. Obnovljeni Život, 26(3), 40-46.

Fuček, Ivan (1971b). U situaciji modernog razvoja. Obnovljeni Život, 26(3), 242-259.

Fuček, Ivan (1971c). Odsutna dimenzija koncilske obnove. Obnovljeni Život, 26(4), 325338.

Fuček, Ivan (1971d). Čovjek pred licem smrti. Obnovljeni Život, 26(6), 507-539.

GS. Gaudium et spes. (7. prosinca 1965.) Drugi vatikanski koncil, Pastoralna konstitucija Gaudium et spes o Crkvi u suvremenom svijetu. U: Josip Turčinović (ur.), II vatikanski koncil: Dokumenti: Latinski i hrvatski (str. 620-768). Zagreb: Kršćanska sadašnjost, 1970.

Häring, Bernhard (1973). Kristov zakon: Prvi svezak: Opća kršćanska moralna teologija. Zagreb: Kršćanska sadašnjost.

International Theological Commision (2009). In Search of a Universal Ethic: A New Look at the Natural Law. The Holy See. URL: http://www.vatican.va/roman_curia/congregations/cfaith/cti_documents/rc_con_cfaith_doc_20090520_legge-naturale_en.html (20.10.2019.)

Irenej (1857). Sancti Ierenaei episcopi Lugdunensis et maryris Detectionis et eversionis falso cognominatae agnitionis seu Contra haereses libri quinque. Patrologia Graeca (PG), vol. 7. Turnholti: Typographi Brepols Editores Pontificii.

Ivaničin, Benjamin (1971). Pluralizam prof. Dragutina Jurića. Obnovljeni Život, 26(2), 140-143.

Kasper, Walter (1996). L'antroplogia teologica della Gaudium et spes. URL: http://www. gliscritti.it/approf/2009/papers/kasper170209.htm (31.08.2019.)

Kasper, Walter (2005). La costituzione pastorale Gaudium et spes. URL: http://www.gliscritti.it/approf/2009/papers/kasper170209.htm (31.08.2019.)

Ladaria, Luis F. (1997). Introduzione alla antropologia teologica: Itroduzione alle discipline teologice. Casale Monferrato (AL): Edizioni Piemme.

Ladaria, Luis F. (2015). Gaudium et spes 22: Un riassunto di antropologia cristiana. Firenze 2015. URL: http://www.firenze2015.it/wp-content/uploads/2015/07/Luis-Ladaria-Gaudium-et-Spes-22.pdf (31.08.2019.)

LG. Lumen genitum. (21. studenoga 1964.) Drugi vatikanski koncil, Dogmatska konstitucija Lumen genitum o Crkvi. U: Josip Turčinović (ur.), II vatikanski koncil: Dokumenti: Latinski i hrvatski (str. 91-204). Zagreb: Kršćanska sadašnjost, 1970.

Lorenzetti, Luigi (2010). La legge naturle nella teologia morale contemporanea. Rivista di teologia morale, 42(3), 421-426.

Milikić, Tadija (2019). The Central Modernist Question: Programmatic Goals and the Broader Intellectual Context of the Journal Život. Obnovljeni Život, 74(5), 647-658.

Mondin, Giovanni Battista (1971). Sekularizacija kristologije. Obnovljeni Život, 26(6), $540-552$.

OT. Optatam totius. (28. listopada 1965.) Drugi vatikanski koncil, Dekret Optatam totius o odgoju i obrazovanju svećenika. U: Josip Turčinović (ur.), II vatikanski koncil: Dokumenti: Latinski i hrvatski (str. 332-357). Zagreb: Krščanska sadašnjost, 1970.

Plačko, Ljudevit (1971). Društveni problemi današnjice. Obnovljeni Život, 26(5), 426-436.

Rousseau, Jean-Jacques (1781). Jean-Jacques Rousseau, citoyen de Geneve, a Christophe de Beaumont. Geneve: bez izdavača. [Edicija: Collection complète des oeuvres de J. J. Rousseau, citoyen de Genève, vol. 6.] 
Sale, Govanni (2007). A un secolo dall'enciclica contro il modernismo. Il contributo della Civiltà Cattolica alla redazione della Pascendi. Civiltà Cattolica, 3775, 9-19.

Schmidt, Stjepan (1971). Dokle smo stigli u ekumenizmu? Obnovljeni Život, 26(2), 177181.

Strilić, Ivan (1971). Problem beskonačnosti materije u sovjetskoj filozofiji. Obnovljeni Život, 26(2), 98-112.

Toma Akvinski (1961-1962). Summa Theologica. Matriti: Biblioteca de Autores Cristianos.

Uredništvo (1919). Što hoćemo. Život, 1(1), 21-22.

Uredništvo (1971). Riječ Uredništva. Obnovljeni Život, 26(1), 1.

Weissgerber, Josip (1971a). Ideja evolucije. Obnovljeni Život, 26(1), 47-54.

Weissgerber, Josip (1971b). Kamo ide moderna psihoterapija? Obnovljeni Život, 26(3), 226-241.

Weissgerber, Josip (1971c). Odakle vjera u evoluciju. Obnovljeni Život, 26(4), 310-324.

\section{The Recognizable Novelty of the Council}

Programmatic Goals and the Broader Intellectual Context of the Journal Obnovljeni Život

\section{Tadija Milikić*}

\section{Summary}

This paper presents an insight into the programmatic goals and broader intellectual context of the journal Obnovljeni Život (Renewed Life) which was first issued under this name in 1971 as the journal which was to carry on the tradition of the journal Život (Life) (1919 - 1944) and which was incorporated into it as though into its proper tradition. The paper firstly introduces in a concise way the foundational and longterm goals of the reissued journal under its new name based on its programmatic text. Then follows a brief insight into the realization of programmatic goals by keeping a foothold in selected papers taken from the journal's first year of publication. Finally, in the central and most important sections of the paper, the reader is given an insight into the broader intellectual context which was strongly influenced by the Second Vatican Council, its novelty and its central turning point. The latter gave rise not only to the spontaneous appearance of the journal Obnovljeni Život, but also to the creative expression and shaping of the historical moment. Just as did the Council Fathers, the authors of the journal Obnovljeni Život strive to contribute to a constructive and fruitful dialogue in the building of a common human family, as well as a unique perspective in understanding man and understanding the world in which man finds himself. Though in their reflections the authors rely on their proper theological, Christian and evangelical principles, the authors of the journal Obnov-

* Tadija Milikić, Ph. D., Faculty of Philosophy and Religious Studies, University of Zagreb. Address: Jordanovac 110, Zagreb, Croatia. E-mail: tmilikic@ffrz.hr 
ljeni Život enter with ease into a dialogue with the world and enhance their thought by accepting the demands of the modern world which are justified, particularly in the area of human autonomy, human freedom and human dignity.

Key words: Obnovljeni Život, scholarly journal, Second Vatican Council, Gaudium et spes, theological anthropology 